\title{
The Intersection of Home Care and HIV with Health and Faith
}

\author{
Ian D Campbell ${ }^{a}$ \\ ${ }^{a} \mathrm{MB}, \mathrm{BS} ; \mathrm{MRCP}(\mathrm{UK}) ;$ DRCOG; MFTM (RCPS-Glasgow), Coordinator, Affirm Facilitation Associates
}

\begin{abstract}
This paper describes significant events in the 1980s in Zambia which involved communities and health institutions in change that is still felt today. The Churches Health Association of Zambia leadership wanted this history to be retold by a leader from the past, and remembered as a vision and values framework that is still relevant. It is experienced as indigenous, describing strengths that are not brought from outside with funding of any kind.

The story still influences an awakening of strength in places far removed from Africa. A recent example is shared from China, where community health and church workers have an intense interest in the development of local initiative in response to HIV.
\end{abstract}

\section{Introduction}

The emergence of HIV and AIDS in Zambia from 1983 illuminated the presence of God as a foundation for healing and expression of care that would generate sustained local community movements for prevention. This paper describes significant events in the 1980s in Zambia that involved communities and health institutions in change still felt today.

In Zambia, and other sub-Saharan African countries, the role of expatriate health workers has changed dramatically in the past thirty years, from heads of institutions in the 1970s through 1990s to occasional consultants and friends. Young Zambians move into senior positions early because of the societal changes brought by decades of HIV impact, and history can be forgotten. The Churches Health Association of Zambia (CHAZ) leadership wanted this history to be retold by a leader from the past and remembered as a vision and values framework that is still relevant. It is experienced as indigenous, describing strengths that are not brought from outside with funding of any kind.

The story still influences an awakening of strength in places far removed from Africa. A recent example is shared from China, where community health and church workers have an intense interest in the development of local initiatives in response to HIV.

The Salvation Army Chikankata Hospital, with neighboring communities in the Southern Province, became a demonstration of response from 1986 with which I was privileged to participate over a seven year period, from 1983 to 1990. The experience has informed global health practice, for me and many others. 


\section{Leprosy and Family Response in Zam- bia}

Chikankata had a leprosy compound in the hospital grounds for more than 40 years. The 450 people who lived there lived a segregated life, rarely visited except by the physiotherapy team and some valiant nurses. When curative treatment became available in the early 1980 s, a team began to facilitate their return to home. Facilitation had to be face-to-face and sustained over several months, in multiple visits, with each family and community, to ensure inclusion in family, engagement in local neighbourhoods, de-stigmatisation, and disability prevention. The results were astounding, with nearly everyone choosing to be repatriated to their villages of origin.

\section{HIV--Is There Another Way?}

Then, along came HIV, or as it was called: HTLV1, 2, then 3. At Chikankata, we saw people with AIDS from 1984; it was clinically recognized from 1986. A donor wanted us to fill the vacant leprosy buildings, but why would we reintroduce segregation?

We needed to respond naturally and in tune with family anxiety, so that the enormity of intergenerational prevention response needed could be fostered right away. We formed an interdisciplinary team and followed people with an HIV diagnosis home, by their invitation. This approach was new and exploratory.

\section{The Word of God in the Home}

I joined a home visit, where we found a woman lying on the ground outside her house. She was weak, tired, lethargic, thin, and listless, soaking up the sun. The team attended her. She had recently been in the hospital for some weeks as a TB inpatient. When I asked her why she would not return to hospital, she said, "The team comes to me!" I asked, "What difference does that make?" She responded, "They take care while I need to be at home. They bring the word of God." There were no Bibles, nothing obvious, but to her it was clear. God was present, comforting, assuring, and healing. Faith and health work together.

\section{The Crossroad of Home, HIV, Faith, and}

\section{Health}

AIDS was a big crossroad that would lead us into new ways of working as health professionals. Gradually, care with the person in their home became linked with potential for change in the family and the surrounding community. If unattended, anxiety would produce stigma, but if community concern about HIV was acknowledged, attitudes would rapidly shift toward personal action and an inclusive hope for the future.

People in the local community could and would change behavior by their choice, because they cared for their family and their future. "Care to change" was defined as a way of working for the team.

\section{Syanyoolo Responds}

Toward the end of 1987, a call was received from a headman in the valley from Syanyoolo. His son was dead, having burned himself alive in his hut as he lay there, unwell from AIDS. The father wanted all the headmen to meet and discuss the prevention of anything like this from happening again. I watched for three hours as the hospital team carefully conversed, listened, reflected, gave back questions, explored meanings, and asked the group for their next steps. The community decision was to act in their families, to move together. Stigma finished in that area for that period that day. I realized that I had experienced a special form of counseling. This was "community counseling.",

\section{Health Teams Respond}

By early 1988, we saw that we could clearly articulate behavior change as community determined. Belief that communities can, and do, initiate 
change stretched the local decision makers, the facilitators, certainly the donors, church leaders, academics, and government.

\section{CHAZ Responds}

The Churches Medical Association of Zambia (CMAZ), as it was then called, took a stand in 1988 by asserting that church involvement in health was about healing relationships as well as body, mind, and spirit. A national home care and community prevention response to HIV was channeled through CMAZ health facilities. In late 1989, a historic partnership with the Zambian Ministry of Health, the Norwegian Agency for Development (NORAD), and CMAZ led to official government policy by 1990 declaring that home care was necessary for long-term effectiveness, impact, and going to scale with local and national responses to HIV.

At the core, it was a choice made by the country to be true to itself. The courage of Zambians, back in 1988 and since, is still an influence on others to find the way to be true to themselves.

\section{An Example of Transfer}

Concepts can transfer; programs of action may not. Part of the global HIV experience is that vision, arising from honest acknowledgement of concern, ignites a fire of agency, responsibility, and ownership that is essentially relational, about ourselves together with those we know and love. ${ }^{2}$

\section{China 1997-2013}

Elvis Simamvwa, from Chikankata, and part of CHAZ, visited Yunnan Province, China in 1997. He met Dr. Wang, then the Provincial leader of the HIV response in Longchuan County. HIV-related home visits were part of the learning experience to encourage local inclusion. It was a radical step at that time in China. Seventeen years later, in March 2013, I met Dr. Wang in Baoshan County as part of an evaluation team. He is a prevention researcher now, and he was excited, because he was seeing change in neighbourhoods, particularly in relation to the link of drug use as well as sexual risk with HIV transmission, both well recognized in that county. We had recently learned that in the nearby county of Longchuan, where we had met originally, 5 of 8 towns in one administrative area had become drug free over an eight-year period, by intensive local community conversation combined with good county level health systems support. ${ }^{3}$

Local responses and inter-country transfer influence sustained care and change over decades. Health and faith intersect with home and HIV, in China as well as in Zambia.

\section{Syanyoolo revisited}

During 2012, a small group returned to Syanyoolo as a component of an Affirm initiative called GloCon ("Global and Local Community Conversation"). ${ }^{4}$

We found a group of headmen and community members having a planning meeting. When we asked whether anyone was present at the meeting, 25 years ago, called by the headman, five people raised their hands. I was sitting next to the brother of the original headman who had died just one month previously. The group was electrified with our recognition of their past. The young men asked where the young man who had died so long ago had been buried, and an older lady said she knew the place. The youths said they needed to create a memorial to the young man to remind them that their community decision to take a journey forward had influenced so many other communities and countries.

\section{Patterns of Response}

Patterns of local response can be discerned globally over years. In 2012, 38 communities in 19 countries were visited and thanked for their resilience, courage, and faith in sustaining responses over decades (see the Global and Local Community Conversation [GloCon] at www.affirmfacilitators.org). ${ }^{4}$ These communities responded on similar principles 
and continue as cost-effective movements for health and faith.

\section{Where Are We?}

Where is a national association such as CHAZ, or a specific mission health entity, in this journey? Most are burdened by task, by scope, and by responsibility. How can Christians in health care remain true to themselves?

We each, and all, want continuing intersections of health and faith. In local community we find who we are, and we meet God, if we wish, because $\mathrm{He}$ is the facilitator of reconciling relationships. With faith, we can imagine anything, and we can speak truth, share burdens, and understand health better, because we know health is indivisible from relationship. We practice more strategically, we mission more effectively, and we manage financially. Can we let this depth be the essence of our future mission journey through home and neighbourhood encounters supported by health systems?

The "home" and "neighbourhood" is where faith, health, and healing can flourish and expand.
Those of us who are part of health systems need to find our way into that intersection.

\section{References}

1. Campbell ID, Rader AD. HIV counselling in developing countries - the link from individual to community counselling for support and change. Brit J Guid Couns. 2002;23(1): n.p. Pubmed PMID:

12290300

http://dx.doi.org/10.1128/JV1.01333-09

2. Campbell ID, Rader AD. AIDS as a development issue. AIDS Care.1991;3(4):395-8.

http://dx.doi.org/10.1080/09540129108251597

3. Campbell ID, Rader A. What can TearFund learn from an Evaluation Experience in China? Reflections with Tearfund (UK) staff, May 2nd 2013 on The Cedar Fund -Church Mobilisation for HIV Prevention Project Evaluation: 1-12 March 2013: n.p. (Contact facilitators for more information: iancampbell11@aol.com; alisonrcam@gmail.com)

4. Affirm [Internet]. London. GloCon: The Global and Local Community Conversation; February 2012-September 2013 [cited March 2014] Available from http://www.affirmfacilitators.org

This article was Peer Reviewed.

Based on a keynote address given at the Churches Health Association of Zambia (CHAZ) Annual Council 19 June 2013

Acknowledgments: Dr. Karen Sichinga, CHAZ; Mr. Elvis Simamvwa, Ministry of Health, Zambia; and Alison Rader Campbell (UK) for collaboration.

Competing Interests: None declared.

Correspondence: Ian Cambell. c/o Interhealth Worldwide, 111 Westminster Bridge Road, London SE1 7HR, UK. iancampbell11@aol.com +447713149203 www.affirmfacilitators.org

Cite this article as: Campbell, Ian, The intersection of home care and HIV with health and faith. Christian Journal for Global Health 2014, 1(1): 53-56.

(C) Campbell, I. This is an open-access article distributed under the terms of the Creative Commons Attribution License, which permits unrestricted use, distribution, and reproduction in any medium, provided the original author and source are properly cited. To view a copy of the license, visit http://creativecommons.org/licenses/by/4.0/

$$
\text { www.cjgh.org }
$$

June 2014. Christian Journal for Global Health 2014, 1(1): 53-56. 